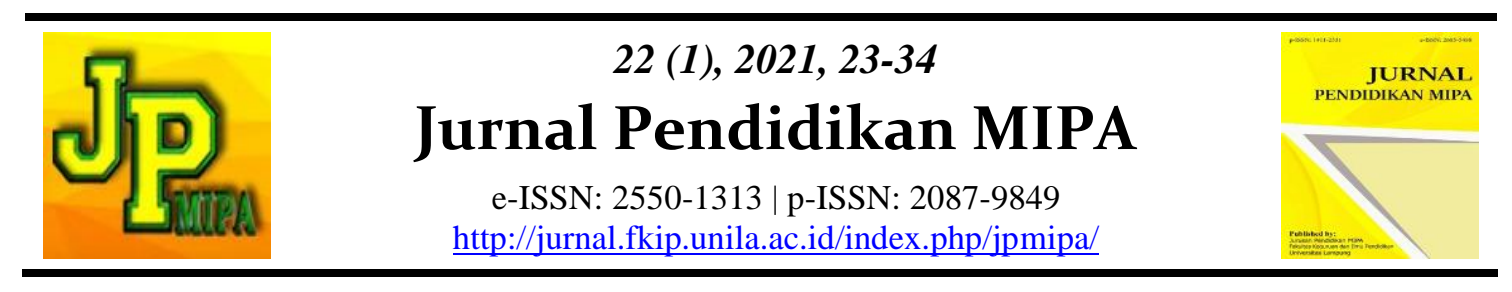

\title{
The Development of STEM-integrated LOIS Learning Unit for Enhancing Students' Direct Current Concept Understanding
}

\author{
Erlita Yuani Putri ${ }^{1}$, Abdurrahman ${ }^{2, *}$, Kartini Herlina ${ }^{2}$, Doni Andra ${ }^{2}$ \\ ${ }^{1}$ Physics Education Teacher, SMAN 1 Tumijajar, Lampung Province, Indonesia \\ ${ }^{2,3,4}$ Graduate Program of Physics Education Department, University of Lampung, Indonesia
}

\begin{abstract}
This study developed the Science, Technology, Engineering \& Mathematics (STEM)integrated Learning of Inquiry Sequences (LOIS) learning unit for students in understanding the direct current concept. Learning unit met the valid, practical, and effective criteria. The validity shows the content validity \& construct validity, the practicality shows the ease of use \& positive response from students, the effectivity shows the achievement of learning objectives namely improvement in understanding the direct current concept. This study used a 4-D learning unit development model namely (define, design, development, and disseminate stages). This study was included in a quasi-experiment study with one group pretest and posttest design. Data were analyzed using descriptive analysis. Based on the results, the mean of content validity was 3.76 and construct validity was 3.75 with very valid criteria. Then, the mean of the learning unit implementation in class was 0.92 and a positive response from students in the class was 0.97 with very practical criteria. Based on paired sample $t$-test $\left(t_{\text {calculation }}=23.291>t_{\text {table }}=2.03011\right)$ and the $\mathrm{N}$-Gain value was 0.80 (high gain) showed that the LOIS learning implementation was effective to engage students in the classroom activities.
\end{abstract}

Keywords: STEM-integrated LOIS learning unit, direct current, concept mastery.

Abstrak: Penelitian ini merupakan penelitian pengembangan dengan mengembangkan produk perangkat pembelajaran Learning Of Inquiry Sequences (LOIS) terintegrasi Science, Technology, Enggineering \& Mathematic (STEM) untuk meningkatkan penguasaan konsep Fisika peserta didik pada materi Rangkaian Listrik Arus Searah. Kelayakan perangkat pembelajaran memenuhi kriteria valid, praktis dan efektif. Valid terdiri atas validitas isi \& validitas konstruks, praktis terdiri dari kemudahan dalam penggunaan \& mendapatkan respon positif dari peserta didik dan Efektif bearti tercapainya tujuan pembelajaran yaitu meningkatnya penguasaan konsep Fisika peserta didik pada materi Rangkaian Listrik Arus Searah. Model pengembangan perangkat pembelajaran menggunakan model 4-D (tahap pendefenisian, tahap perancangan, tahap pengembangan dan tahap penyebaran). Penelitian ini termasuk penelitian quasi ekperimen dengan desain one groups pretest dan posttest. Data dianalisa menggunakan analisis deskriptif. Berdasarkan hasil validitas perangkat pembelajaran diperoleh skor rerata validitas isi dan vaiditas konstruks sebesar 3,76 dan 3,75 dengan kriteria sangat valid. Kedua adalah kepraktisan perangkat pembelajaran diperoleh skor rerata dari keterlaksanaan perangkat pembelajaran dikelas sebesar 0,92 dan skor rerata respon positif peserta didik dikelas sebesar 0,97 dengan kriteria sangat praktis. Berdasarkan hasil uji paired sample $t$-test $\left(t_{\text {hitung }}=23,291\right.$ > $\left.t_{\text {tabel }}=2,03011\right)$ dan nilai $N$-Gain yang diperoleh sebesar 0,80 (gain tinggi) menunjukkan bahwa pelaksanaan pembelajaran LOIS efektif untuk melibatkan siswa dalam aktivitas kelas.

Kata kunci: perangkat pembelajaran LOIS terintegrasi STEM, rangkaian listrik arus searah, penguasaan konsep peserta didik.

Erlita Yuani Putri et al.

Corresponding Email:

abdurrahman.1968@fkip.unila.ac.id
DOI: http://dx.doi.org/10.23960/jpmipa/v22i1.pp23-34

Received: 07 February 2021

Accepted: 25 March 2021 


\section{INTRODUCTION}

The development of information technology and the emergence of various complex environmental problems are future challenges that must be faced in the 21 st century. Trilling, Bernie \& Fadel (2009) stated that life skills to face these challenges include: (1) learning and innovation skills such as critical thinking and being able to solve problems, being creative and innovative, and being able to communicate and collaborate; (2) skills to use media, Information \& Communication Technology (ICT); and (3) skills to live a life and career, such as adaptability, flexibility, initiative, self-development, social and cultural abilities, productive, trustworthy, leadership, and responsibility. Therefore, it is necessary to develop 21 st-century skills from an early age in planning the implementation of learning in schools. 21st-century skills that must be present in learning include creativity, critical thinking, collaboration, and communication (Kennedy \& Sundberg, 2020).

The challenge of developing 21st-century skills in learning is one of the reasons for the government to revise the 2006 curriculum to the 2013 curriculum (Fernandes, 2019; Kusumaningrum \& Djukri, 2016). Changes to the 2013 curriculum include four elements of the National Education Standards (SNP) namely Graduate Competency Standard, Content Standard, Process Standard, and Assessment Standard (Nopriana, Nopitasari \& Dahlan, 2020; Slameto, 2015). This is the basis for the development of learning unit. Ministerial Regulation of Education and Culture No. 22 of 2016 requires teachers to develop a learning unit in the form of a syllabus and lesson plan (RPP).

The 2013 curriculum requires every educator to compile a learning unit designed to face the challenges of the 21st century. STEM is very suitable to be applied in the 2013 curriculum learning (Aninda, Permanasari \& Ardianto, 2020; Fathoni et al., 2020; Setiawan, Sutrisno, Munzil \& Danar, 2021). STEM is a learning approach that connects four fields into a holistic whole (Bybee, 2013; Roberts dan Cantu, 2012). Based on the results, STEM implementation can improve concept mastery (Khotimah \& Supriana, 2020; Nisa et al., 2020; Nuangchalerm et al., 2020; Thahir et al., 2020).

Physics material in XII class consists of 12 basic competencies, while the effective week time available becomes a burden for the teacher to complete all the materials. So, at the time of learning, the teacher directly teaches the formulas and exercises only so that the learning seems to be teacher-centered. Teachers rarely do practicum activities because of insufficient time. Based on the analysis, 69 high school students in West Tulang Bawang Regency in 2017/2018, the mean score of physics was in the D category (low). The materials were Measurement and Kinematics (32.17), Dynamics (35.59), Work \& Energy and Collisions (32.17), Heat (39.86), Waves and Light (40.34), Electric Magnets and Core Physics (37.84). This shows low mastery of physics concepts. The concept of electricity is often a problem with the direct current (Rusilowati, 2012).

Based on these facts, it is important to develop a learning unit that can improve $21 \mathrm{st}-$ century skills and can be implemented according to the needs of teachers, especially in $12^{\text {th }}$ grade secondary school materials. Although the time to teach material is relatively short, it can achieve the expected competencies and learning objectives. However, teaching physics using practicum is important so that it is easy to understand. Through the practicum, students are given the opportunity to experience themselves, follow a process, observe an object, analyze, prove and draw their own conclusions about an object, state, or process so that students can master the concepts of physics well (Zakwandi et al., 2020). The limitations of practicum tools, the long time to prepare the 
practicum, and the short time allocation are obstacles for practicum activities in the laboratory so that the use of electronic learning is needed. One of them is using virtual labs with the PhET Simulation program. This learning has the advantage in which students can interact virtually directly with the material being studied without requiring a long time. The PhET simulation is a simulation created by the University of Colorado (Bajpai, 2013). Virtual Labs can make it easier for students to do a practicum and understand concepts (Hermansyah, Gunawan \& Herayanti, 2015).

STEM implementation in learning can be integrated into learning models or methods such as using inquiry learning. Learning using inquiry can improve mastery of physics concepts (Sani, 2011; Wahyuni, Kosim \& Gunawan, 2018). The stages of inquiry learning were introduced by Wening (2005) with an inquiry learning formula consisting of 6 stages arranged hierarchically with learning stages in the form of Level of Inquiry (LOI): discovery learning, interactive demonstrations, inquiry lessons, inquiry labs, and hypothetical inquiry. Wening (2010) stated that its entirety is intended to be suggestive, not definitive, meaning that the learning stages developed are very open to modification. Based on the above background, the authors developed a STEM-integrated LOIS learning unit in understanding the direct current concept. Furthermore, this study aimed to develop of validity, practically, and effectiveness STEM-integrated LOIS learning unit.

\section{METHOD}

\section{Design \& Procedures}

This study used a 4-D learning unit development model with define stage, design stage, development stage, and disseminate stage (Thiagarajan, 1974). The define stage aims to define learning goals. The design stage aims to design a draft learning unit development. The develop stage aims to test the learning unit validity through validation and expert judgment so that they can be tested in the field. The disseminate stage aims to introduce a product that has been developed on a wider scale. In this stage, the disseminate stage was limited to seminars and journal submissions. This study was included in a quasiexperiment study with one group pretest and posttest design (Sugiyono, 2015).

\section{Population and Sample}

This study was conducted in SMAN 1 Tumijajar located at Jl. Jendral Sudirman No.92 Dayamurni Village, Tumijajar Sub-District, West Tulang Bawang Regency. This study was conducted in XII class in the odd semester of the 2019/2020 school year from 22 August 2019 to 06 September 2019. The sample was 36 XII IPS 3 students who took physics. This study used the purposive sampling technique.

\section{Data Collection and Instrument}

The collected data were: (1) validity test data from the learning unit validation sheet, (2) practicality test data from the learning implementation observation sheet filled out by the observer teacher and student response questionnaires, and (3) effectiveness test data obtained from the mastery test results before and after using STEM-integrated LOIS learning unit.

\section{Data Analysis}

The data analysis were (1) validity data analysis by three expert validators who then recapitulated the mean value of each criterion, the mean for each aspect, and the total 
mean and determined the category of the validity criteria (V) based on (Trianto, 2010) with several categories namely very valid $(3.5 \leq \mathrm{V} \leq 4)$, valid $(2.5 \leq \mathrm{V}<3.5)$, fairly valid $(1.5 \leq \mathrm{V}<2.5)$ and not valid $(0 \leq \mathrm{V}<1.5)$; (2) practicality data analysis from the observation sheet on the implementation of teacher learning in the classroom by the observer, and the response questionnaire of 36 students after using STEM-integrated LOIS with answers from each instrument using a Likert scale with 1 to 4 weights and determining categories of practicality criteria based on (Riduwan, 2009) with several categories namely very low interval $(0.00 \leq \mathrm{Kr} \leq 0.20)$, low $(0.20<\mathrm{Kr} \leq 0.40)$, fair $(0.40<\mathrm{Kr} \leq 0,60)$, high $(0.61<\mathrm{Cr} \leq$ $0.80)$ and very high $(0.80<\mathrm{Kr} \leq 1.00)$; and (3) effectiveness data analysis from test results of pretest - posttest and N-Gain Score with several categories namely high criteria if $\mathrm{N}$ Gain $>0.7$, fair if $0.3<\mathrm{N}$-Gain $\leq 0.7$ and low if $\mathrm{N}-$ Gain $\leq 0.3$ (Hake, 1999). In addition, the data were analyzed using Microsoft Excel and statistically analyzed using SPSS version 21.0 for windows including the Kolmogorov Smirnov normality test and paired t-test.

\section{RESULT AND DISCUSSION}

The product developed in this study was a STEM-integrated LOIS learning unit to improve the understanding of the direct current concept. Learning unit validation aimed to describe the validity of the learning unit in a study. The description of the learning unit validation was obtained by referring to the assessments and suggestions of competent experts. Data validity includes content validity and constructs validity.

Content validity includes syllabus assessment, lesson plan assessment, student worksheet stage assessment, STEM assessment in learning, Learning of Inquiry assessment, and language assessment in student assessment. Construct validity includes the student worksheet assessment, social system assessment, reaction principles assessment, and support system assessment. The summary of content validity and construct validity can be seen in Table 1 and Table 2 below.

Table 1. Summary of content validity

\begin{tabular}{llccccc}
\hline \multirow{2}{*}{ No } & \multirow{2}{*}{ Aspect } & \multicolumn{3}{c}{ Result } & \multirow{2}{*}{ Category } \\
\cline { 3 - 5 } & & $\begin{array}{c}\text { Expert } \\
\text { I }\end{array}$ & $\begin{array}{c}\text { Expert } \\
\text { II }\end{array}$ & $\begin{array}{c}\text { Expert } \\
\text { III }\end{array}$ & & \\
\hline 1 & Syllabus & 3.76 & 3.69 & 3.84 & 3.77 & Very Valid \\
\hline 2 & Learning Plan & 3.75 & 3.81 & 3.83 & 3.80 & Very Valid \\
\hline 3 & Student Worksheet & 3.60 & 3.84 & 3.88 & 3.77 & Very Valid \\
\hline 4 & STEM in Learning & 3.40 & 3.80 & 3.80 & 3.67 & Very Valid \\
\hline 5 & LOIS Stage in studentworksheet & 3.50 & 3.67 & 3.67 & 3.61 & Very Valid \\
\hline 6 & $\begin{array}{l}\text { Language Assessment in } \\
\text { studentworksheet }\end{array}$ & 3.62 & 3.62 & 3.92 & 3.72 & Very Valid \\
\hline \multicolumn{2}{c}{ Total } & $\mathbf{3 . 6 1}$ & $\mathbf{3 . 7 4}$ & $\mathbf{3 . 8 2}$ & $\mathbf{3 . 7 6}$ & Very Valid \\
\hline
\end{tabular}

Table 2. Summary of construct validity

\begin{tabular}{clccccc}
\hline \multirow{2}{*}{ No } & \multirow{2}{*}{ Aspect } & \multicolumn{3}{c}{ Result } & & \\
\cline { 3 - 5 } & & $\begin{array}{c}\text { Expert } \\
\text { I }\end{array}$ & $\begin{array}{c}\text { Expert } \\
\text { II }\end{array}$ & $\begin{array}{c}\text { Expert } \\
\text { III }\end{array}$ & & Category \\
\hline 1 & Student Worksheet stage & 3.40 & 4.00 & 4.00 & 3.80 & Very Valid \\
\hline 2 & Social System & 3.75 & 3.50 & 3.75 & 3.67 & Very Valid \\
\hline 3 & Reaction Principles & 4.00 & 4.00 & 4.00 & 4.00 & Very Valid \\
\hline 4 & Support System & 3.40 & 3.40 & 3.60 & 3.47 & Valid \\
\hline
\end{tabular}




\begin{tabular}{|c|c|c|c|c|c|c|}
\hline 5 & $\begin{array}{l}\text { Instructional and Accompaniment } \\
\text { Impact }\end{array}$ & 3.75 & 3.75 & 4.00 & 3.83 & Very Valid \\
\hline & Total & 3.66 & 3.73 & 3.87 & 3.75 & Very Valid \\
\hline
\end{tabular}

The development of STEM-integrated LOIS learning unit for components contained in the syllabus and learning plan following the rules of the Ministerial Regulation of Education and Culture No. 22 of 2016 based on graduate competency standards and content standards according to the attachment to the Ministerial Regulation of Education and Culture No. 22 of 2016 and determining indicators of achievement based on the Ministerial Regulation of Education and Culture No. 38 of 2018, while the steps for learning activities in the student worksheet follow the inquiry developed by Wening learning stages with six learning stages integrated with STEM. The learning plan design of STEM-integrated LOIS carries out practicum activities using Virtual Labs in the form of a PhET simulation program as well as when designing and designing projects that will be applied in real terms in making products as project activities. The content validation sheet consists of 6 assessment aspects with 85 questions in total, while the construct validation sheet consists of 5 assessment aspects with 22 questions in total. Based on the results of the validation in Table 1 and Table 2 above, the mean value of the three validators from each component for content validity and construct validity was in the range of $3.6 \leq \mathrm{P} \leq 4$ so that the overall mean value of the total validity for content validation and construct validation of STEM-integrated LOIS learning unit were 3.76 and 3.75 and were very valid and feasible to be tested in the field (Taherdoost, 2016; Trianto, 2010).

In the trial of using STEM-integrated LOIS learning unit, data were obtained from the observations of the implementation of STEM integrated LOIS learning implementation tools, which were assessed by 2 teacher observers covering 4 aspects of assessment with 20 total questions and questionnaire data on responses to the implementation of STEM-based LOIS learning which was filled in by 36 students after using STEM-integrated LOIS covering 3 aspects of assessment with 30 total questions in total. The calculation of observations on the implementation of STEM-integrated LOIS learning and questionnaire responses of students can be in Table 3 and Table 4.

Table 3. Observation of STEM-integrated LOIS learning unit implementation

\begin{tabular}{|c|c|c|c|c|c|}
\hline \multirow[b]{2}{*}{ No } & \multirow[b]{2}{*}{ Aspect } & \multicolumn{2}{|c|}{ Result } & \multirow[b]{2}{*}{ Mean } & \multirow[b]{2}{*}{ Category } \\
\hline & & $\begin{array}{c}\text { Observer } \\
\text { I }\end{array}$ & $\begin{array}{c}\text { Observer } \\
\text { II }\end{array}$ & & \\
\hline 1 & STEM integration in learning & 18 & 18 & 0.90 & Very High \\
\hline 2 & LOIS learning syntax & 25 & 27 & 0.93 & Very High \\
\hline 3 & Social Interaction & 15 & 14 & 0.91 & Very High \\
\hline 4 & Reaction Principles & 15 & 14 & 0.91 & Very High \\
\hline & Total & 73 & 73 & 0.91 & Very High \\
\hline
\end{tabular}

Table 4. Students response toward learning implementation

\begin{tabular}{clccc}
\hline No & \multicolumn{1}{c}{ Aspect } & $\sum$ Student & Mean & Category \\
\hline 1 & Learning process & 36 & 0.96 & Very High \\
\hline 2 & $\begin{array}{l}\text { STEM-integrated LOIS student } \\
\text { worksheet }\end{array}$ & 36 & 0.95 & Very High \\
\hline
\end{tabular}




\begin{tabular}{ccccc}
\hline No & Aspect & EStudent & Mean & Category \\
\hline 3 & $\begin{array}{l}\text { PhET Simulation } \\
\text { Implementation }\end{array}$ & 36 & 0.98 & Very High \\
\hline Total & & 0.97 & Very High \\
\hline
\end{tabular}

The results and analysis of observational data of STEM-integrated LOIS to improve communication skills and collaboration skills can be seen in Table 3 that the mean observer assessment for each aspect of the assessment was in the range $0.80<\mathrm{Kr} \leq 1.00$ and in the very high practicality category, as well as the results of student responses can be seen in Table 4 meaning for each aspect of the assessment was in the range $0.80<\mathrm{Kr}$ $\leq 1.00$ and in the very high practicality category. Based on the results of teacher observer assessments and responses of students on STEM-integrated LOIS learning, practical media can be used in the field (Riduwan, 2009).

As for the steps in implementing STEM-integrated LOIS learning, the researchers analyzed the STEM learning material and then integrated it into the Learning Of Inquiry (LOI) learning stage. Analysis of STEM Integrated Direct Current Electric Circuit material includes: (1) Science consists of the direct current electric source material, Ohm's Law, Series and Parallel Combinations of Electric Circuits, Kirchoff's Laws 1 and 2, and Power \& Electrical Energy; (2) Technology consists of implementing the PhET Simulation program to design Direct Current Circuits, using the internet to conduct literature studies and using presentation applications to communicate product designs from STEM, (3) Engineering consists of designing various Series-Parallel electric current circuits, making a product of series-parallel electric currents based on the design made and testing \& revising the product, (4) Mathematics consists of finding mathematical equations for Ohm's law, series-parallel electric circuits, and Kirchoff's law equations 1 and 2. Learning activities carried out by students using STEM-integrated LOIS learning on the Direct Current Electric Circuit material can be seen in Table 6 .

Table 6. STEM-integrated LOIS learning activities of direct current

\begin{tabular}{|c|c|c|}
\hline Stage & Learning Activities & Concept achieved \\
\hline $\begin{array}{l}\text { Discovery Learning } \\
\text { (Students develop } \\
\text { concepts based on } \\
\text { direct experience) }\end{array}$ & $\begin{array}{l}\text { Learning flow } \\
\text { Students mention various } \\
\text { electrical devices, define sources } \\
\text { of direct current electric current, } \\
\text { make electrical circuits, write } \\
\text { down electrical quantities, view } \\
\text { simulations, and or perform } \\
\text { demonstrations of making } \\
\text { electrical circuits and measuring } \\
\text { electrical quantities using the } \\
\text { Virtual Labs PhET Simulation } \\
\text { program and in groups working } \\
\text { on student worksheets. }\end{array}$ & $\begin{array}{l}\text { 1. Citing examples of DC } \\
\text { sources and AC currents } \\
\text { 2. Defining direct current } \\
\text { (DC) electric circuits } \\
\text { 3. Explaining the meaning } \\
\text { of electrical quantities and } \\
\text { their measuring } \\
\text { instruments } \\
\text { 4. Explaining to use the } \\
\text { Amperemeter and } \\
\text { Voltmeter in an electrical } \\
\text { circuit }\end{array}$ \\
\hline $\begin{array}{l}\text { Interactive } \\
\text { Demonstration } \\
\text { (Students are involved } \\
\text { in explanation and } \\
\text { prediction) }\end{array}$ & $\begin{array}{l}\text { Learning flow } \\
\text { Students create electrical circuits } \\
\text { using Virtual Labs through a } \\
\text { PhET simulation program, } \\
\text { install a voltmeter and } \\
\text { amperemeter in a circuit, } \\
\text { measure, observe and record }\end{array}$ & $\begin{array}{l}\text { Graphing the relationship } \\
\text { between V, I, and R based } \\
\text { on observational data } \\
\text { Formulating Ohm's Law } \\
\text { and the quantities } \\
\text { affecting it }\end{array}$ \\
\hline
\end{tabular}




\begin{tabular}{|c|c|c|}
\hline Stage & \begin{tabular}{l}
\multicolumn{1}{c}{ Learning Activities } \\
data, graph the relationship \\
between voltage and electric \\
current, formulate Ohm's law \\
based on the results of \\
experiments and literature \\
studies, and in groups work on \\
students worksheet.
\end{tabular} & Concept achieved \\
\hline $\begin{array}{l}\text { Inquiry Lessons } \\
\text { (Students identify } \\
\text { principles and/or } \\
\text { scientific relationships) }\end{array}$ & $\begin{array}{l}\text { Learning flow } \\
\text { Students conduct literature } \\
\text { studies to write types of } \\
\text { electrical circuits, design series } \\
\text { \& parallel arrangement of } \\
\text { electric circuits by trying to use } \\
\text { the PhET program, record the } \\
\text { electrical quantities that appear, } \\
\text { identify differences in the } \\
\text { amount of electric current and } \\
\text { the total voltage of the series \& } \\
\text { parallel arrangement of electric } \\
\text { circuits made, and write a } \\
\text { mathematical equation for the } \\
\text { total resistance of the two series, } \\
\text { and in groups work on a student } \\
\text { worksheet. }\end{array}$ & $\begin{array}{l}\text { 5. Calculating the amount of } \\
\text { electric current and } \\
\text { voltage from the } \\
\text { measurement results } \\
\text { 6. Formulating the amount } \\
\text { of electric current, } \\
\text { voltage, and total } \\
\text { resistance of series and } \\
\text { parallel circuits }\end{array}$ \\
\hline $\begin{array}{l}\text { Inquiry Labs } \\
\text { (Students make } \\
\text { empirical laws based on } \\
\text { variable measurements) }\end{array}$ & $\begin{array}{l}\text { Learning flow } \\
\text { Students design electric circuits } \\
\text { for mixed series and parallel } \\
\text { arrangements and make them in } \\
\text { a PhET simulation program, } \\
\text { observe the amount of current, } \\
\text { voltage from each branch in the } \\
\text { electrical circuit, make } \\
\text { mathematical equations based } \\
\text { on analysis of the data obtained } \\
\text { and calculate the electrical } \\
\text { resistance based on Ohm's law } \\
\text { and compare it with the } \\
\text { resistance of the lamp. contained } \\
\text { in the data, and independently } \\
\text { work on student worksheets }\end{array}$ & $\begin{array}{l}\text { 7. Formulating the amount } \\
\text { of electric current, } \\
\text { voltage, and total } \\
\text { resistance of a series- } \\
\text { parallel (mixed) electric } \\
\text { circuit }\end{array}$ \\
\hline $\begin{array}{l}\text { Real Word Aplication } \\
\text { (Students solve problems } \\
\text { related to authentic } \\
\text { situations by using } \\
\text { problem-based and } \\
\text { project-based learning) }\end{array}$ & $\begin{array}{l}\text { Learning flow } \\
\text { Students work in groups to solve } \\
\text { a problem, students design a } \\
\text { product to be made with their } \\
\text { own creativity, then work } \\
\text { together to determine one } \\
\text { selected product to be made, the } \\
\text { product is tested and then } \\
\text { presented, and in groups work } \\
\text { on student worksheets }\end{array}$ & 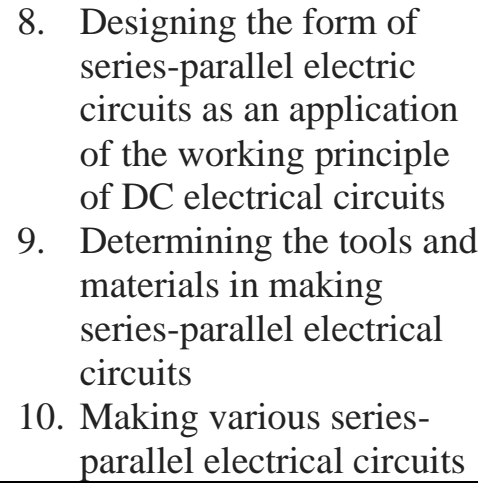 \\
\hline
\end{tabular}




\begin{tabular}{|c|c|c|}
\hline Stage & Learning Activities & Concept achieved \\
\hline & & $\begin{array}{l}\text { 11. Testing and } \\
\text { communicating the work }\end{array}$ \\
\hline $\begin{array}{l}\text { Hypothetical Inquiry } \\
\text { (The students produced } \\
\text { hypotheses/explanations } \\
\text { for the observed } \\
\text { phenomena) }\end{array}$ & $\begin{array}{l}\text { Learning flow } \\
\text { Students pay attention to various } \\
\text { questions about electrical } \\
\text { circuits, make temporary } \\
\text { hypotheses and carry out } \\
\text { experimental activities, observe } \\
\text { and write mathematical } \\
\text { equations and make conclusions } \\
\text { to solve these problems using } \\
\text { PhET simulations, and in groups } \\
\text { work on student worksheets }\end{array}$ & $\begin{array}{l}\text { 12. Formulating the Kirchoff } \\
\text { I and II equations } \\
\text { 13. Calculating electrical } \\
\text { quantities using Kirchoff's } \\
\text { law equations I and II } \\
\text { 14. Analyzing the working } \\
\text { principle of DC } \\
\text { unidirectional electrical } \\
\text { equipment in everyday } \\
\text { life }\end{array}$ \\
\hline
\end{tabular}

The effectiveness test of the STEM-integrated LOIS learning unit development product to improve the conceptual mastery of Direct Current Electric Circuits was obtained through data analysis of the pretest and posttest. The results of data analysis on the pretest and posttest values can be seen in Table 7 .

Table 7. Result of concept mastery

\begin{tabular}{ccccccccc}
\hline Data & $\begin{array}{c}\text { Total } \\
\text { Students }\end{array}$ & $\begin{array}{c}\text { Total } \\
\text { Questions }\end{array}$ & $\begin{array}{c}\text { Low } \\
\text { Score }\end{array}$ & $\begin{array}{c}\text { High } \\
\text { Score }\end{array}$ & Std-D & $\begin{array}{c}\text { Mean } \\
\text { Score }\end{array}$ & $\begin{array}{c}\text { N- } \\
\text { Gain }\end{array}$ & Category \\
\cline { 1 - 8 } Pre-test & 36 & 10 & 10 & 60 & 15.11 & 36.67 & 0,8 & High \\
\hline Post-test & 36 & 10 & 70 & 100 & 12.53 & 84.72 & & \\
\hline
\end{tabular}

The pre-test and post-test normality test as a prerequisite for paired sample t-test analysis was obtained by the Kolmogorov-Smirnov normality test. From the results of the analysis of the normality test, it was found that the pre-test significance value was 0.0457 and the post-test significance value was 0.272 . Both significance values are greater than 0.05 , so both pre-test and post-test were normally distributed. The results of the paired sample t-test analysis on the pre-test and post-test values showed that the difference in mean between the post-test and pre-test was 48.06, where the mean post-test was $84.72>$ the mean pre-test was 36.67 . This difference was in the $95 \%$ confidence interval, namely, the lowest was 43.86 and the highest was 52.24. The $t$ value was 23.291 with a significance (2-tailed) of $0.000<0.05$. The $t$ value obtained was far higher than the table of 2.03011 so it can be seen that there was a significant difference between the concept mastery before (pre-test) and after (post-test) STEM-integrated LOIS learning was carried out on the concept of Direct Current Electric Circuits. The effectiveness of STEMintegrated LOIS learning in improving the mastery of physics concepts on direct current electric circuits was measured by the $\mathrm{N}-$ Gain test mean value. The $\mathrm{N}-\mathrm{Gain}$ value obtained from the pre-test and post-test values was 0.80 . This value was in the $\mathrm{N}-$ Gain range $>0.7$ including a high gain (Hake, 1999).

The research results indicated that the students increased their conceptual understanding about direct current concept after engaging in the STEM-integrated LOIS learning unit activities. The STEM-integrated LOIS learning units are designed so that each stage of learning activities is carried out sequentially and systematically starting with students being able to find a concept in groups and independently starting from a low to high concept mastery structure adjusted to the achievement of indicators to achieve basic competence in knowledge and expected skills. In the implementation of STEM-integrated 
LOIS learning activities, starting from the stage, students are able to find concepts through observing the surrounding environment, seeing demonstrations, conducting simulations, direct experience during practicum activities, designing a product, making products, testing products, and presenting products. The practicum activity in the STEM-integrated LOIS learning design used the Virtually Labs assisted by the PhET simulation program. This is due to anticipate the efficiency of time and the limitations of practicum tools. This result suggested that STEM learning strategies in principle can be developed flexibly and focus on how to actively involve students in every learning experience that is designed in such a way that their learning potential can work optimally (Abdurrahman et al., 2019).

Product developing activities as a project task to be simple, minimized financing, and do not require a long time because the completion time of making the products made is within the learning time in class. This was performed so that the collaborative work activities of students in groups during product design, product manufacture, and product testing and presentation of products can actually be monitored and observed directly by the teacher as well as student interaction between fellow groups, between other group students and teachers. So that, at the end of the learning activities, the teacher and students can directly make conclusions on the material that has been studied. The results of the implementation of STEM-integrated LOIS learning showed a significant improvement in the mastery of concepts regarding the material of Direct Current Electric Circuits that had been taught. This improvement is evidence that this learning unit has succeeded in providing a positive impact on increasing the assessment of knowledge. The stages of LOIS learning which are carried out in sequence and guided in student worksheets can help students to understand concepts in stages. This is also supported by several studies that prove that guided learning can improve the mastery of physics concepts (Pramudyawan et al., 2019; Siahaan et al., 2021).

Students as a whole learning experience involving thinking activities through practicum activities, designing various DC products using virtual labs with the PhET simulation program. This is in line with the results of the study using virtual labs to improve the physics concepts (Salam, Setiawan \& Hamidah, 2010; Sugiana et al., 2017). In addition, in the STEM-integrated LOIS, students will be contextually involved in physical activity through the production of various direct current electric circuit products which also have an effect on improving physics concepts. This study was also supported by several studies stating that inquiry learning integrated with the STEM approach can improve the physics concepts (Komarudin, Suherman \& Anggraini, 2021; Mahjatia, Susilowati \& Miriam, 2021). However, as in general a STEM learning strategy, in order for optimal results in developing student academic potential, it still requires proper scaffolding from the teacher in each phase of learning activities (Nurulsari et al., 2017).

\section{CONCLUSION}

The results of STEM-integrated LOIS learning unit development were in the form of a syllabus, learning plan, and student worksheet of Direct Current for use in high school physics learning and are effective in improving the mastery of physics concepts. Thus, it is recommended that the STEM-integrated LOIS learning unit can only be developed for all physics materials whose material concepts produce mathematical equations that can be proven using measuring instruments. In addition, the use of various teaching materials media can be applied in STEM-integrated LOIS learning so that better device products can be produced and the learning objectives to be achieved can be maximally realized. 


\section{ACKNOWLEDGMENTS}

The author would like to thank the validators and experts who helped evaluate the learning unit feasibility in use.

\section{REFERENCES}

Abdurrahman, Ariyani, F., Maulina, H., \& Nurulsari, N. (2019). Design and validation of inquiry-based STEM learning strategy as a powerful alternative solution to facilitate gift students facing 21 st century challenging. Journal for the Education of Gifted Young Scientists, 7(1), 33-56.

Aninda, A., Permanasari, A., \& Ardianto, D. (2020). Implementasi Pembelajaran Berbasis Proyek Pada Materi Pencemaran Lingkungan untuk Meningkatkan Literasi STEM Siswa SMA. Journal of Science Education and Practice, 3(2), 1-16.

Bajpai, M. (2013). Developing concepts in physics through virtual lab experiment: An effectiveness study. International Journal of Educational Technology, 3(1), 43-50.

Bybee, R. (2013). The case for STEM education: Challenges and opportunity. Airlington, VI.

Fathoni, A., Muslim, S., Ismayati, E., Rijanto, T., Munoto, \& Nurlaela, L. (2020). STEM : Inovasi Dalam Pembelajaran Vokasi. Jurnal Pendidikan Teknologi Dan Kejuruan, 17(1), 33-42.

Fernandes, R. (2019). Relevansi Kurikulum 2013 dengan kebutuhan Peserta didik di Era Revolusi 4.0. Jurnal Socius: Journal of Sociology Research and Education, 6(2), 70-80.

Hake, R. R. (1999). Analyzing change/gain scores. Unpublished.[online] URL: http://www. physics. indiana. edu/ sdi/AnalyzingChange-Gain.pdf.

Hermansyah, H., Gunawan, G., \& Herayanti, L. (2015). Pengaruh penggunaan laboratorium virtual terhadap penguasaan konsep dan kemampuan berpikir kreatif siswa pada materi getaran dan gelombang. Jurnalfkip.Unram.Ac.Id, I(2), 24076902.

Kennedy, T. J., \& Sundberg, C. W. (2020). 21 st Century Skills. In Science Education in Theory and Practice. Springer, Cham.

Khotimah, K., \& Supriana, E. (2020). Pengaruh Inkuiri Terbimbing Berbasis Science , Technology, Engineering, Math ( STEM ) terhadap Penguasaan Konsep Siswa SMA pada Materi Fluida Statis. Jurnal Pendidikan, 2016, 896-901.

Komarudin K, Suherman S, A. A. (2021). Analysis of Mathematical Concept Understanding Capabilities: The Impact of Makerspae STEM Learning Approach Models and Student Learning Activities. Journal of Innovation in Educational and Cultural Research, 2(1), 35-43.

Kusumaningrum, S., \& Djukri, D. (2016). Development of project based learning (PjBL) learning tools to improve skills in the process of science and creativity. Jurnal Inovasi Pendidikan IPA, 2(2), 241-251.

Mahjatia, N., Susilowati, E., \& Miriam, S. (2021). Pengembangan LKPD Berbasis STEM untuk Melatihkan Keterampilan Proses Sains Siswa Melalui Inkuiri Terbimbing. Jurnal Ilmiah Pendidikan Fisika, 4(3), 139-150.

Nisa, I. K., Yuliati, L., \& Hidayat, A. (2020). Analisis Penguasaan Konsep melalui Pembelajaran Guided Inquiry berbantuan Modul Terintegrasi STEM pada Materi Fluida Dinamis. Jurnal Pendidikan, 5(6), 809-816.

Nopriana, T., Nopitasari, D., \& Dahlan, J. A. (2021). Mathematics Teachers' 
Understanding in Developing Learning Indicators in Preparing Lesson Plans. Pedagogia: Jurnal Pendidikan, 10(1), 21-34.

Nuangchalerm, P., Prachagool, V., El Islami, R. A. Z., \& Abdurrahman, A. (2020). Contribution of Integrated Learning through STEM Education in ASEAN Countries. Jurnal Pendidikan Progresif, 10(1), 11-21.

Nurulsari, N., \& Suyatna, A. (2017, November). Development of soft scaffolding strategy to improve student's creative thinking ability in physics. In Journal of Physics: Conference Series (Vol. 909, No. 1, p. 012053). IOP Publishing.

Pramudyawan, M. T. S., \& Doyan, A. (2020). Pengaruh Model Pembelajaran Inkuiri Terbimbing Berbantuan Kit Alat Percobaan Usaha dan Energi terhadap Penguasaan Konsep Fisika Peserta didik. Jurnal Penelitian Pendidikan IPA, 6(1), 40-44.

Riduwan. (2009). Skala Pengukuran Variabel-Variabel Penelitian. Alfabeta.

Roberts, A. dan Cantu, D. (2012). Applying STEM Instructional Strategies to Design and Technology Curriculum. Departement of STEM Education and Professional Studies Old Dominion University.

Rusilowati, A. (2012). Profil Kesulitan Belajar Fisika Pokok Bahasan Kelistrikan Siswa Sma Di Kota Semarang. Jurnal Pendidikan Fisika Indonesia, 4(2), 1-1. https://doi.org/10.15294/jpfi.v4i2.163

Salam, H., Setiawan, A., \& Hamidah. (2010). Pembelajaran berbasis virtual laboratory untuk meningkatkan penguasaan konsep pada materi listrik dinamis. The 4th International Conference on Teacher Education, November, 688-692.

Sani, R. A. (2011). Pengaruh Model Pembelajaran Inquiry Training (Latihan Inkuiri) terhadap Penguasaan Konsep Fisika Siswa Kelas X SMA Negeri 1 Tanjung Beringin. Jurnal Penelitian Inovasi Pembelajaran Fisika, 3(01), 43-48.

Setiawan, N. C. E., Sutrisno, S., Munzil, M., \& Danar, D. (2021). Pengenalan STEM (Science, Technology, Engineering, And Mathematics) dan Pengembangan Rancangan Pembelajarannya untuk Merintis Pembelajaran Kimia dengan Sistem SKS di Kota Madiun. Lumbung Inovasi: Jurnal Pengabdian Kepada Masyarakat, 5(1), 79-89.

Siahaan, K. W. A., Lumbangaol, S. T., Marbun, J., Nainggolan, A. D., Ritonga, J. M., \& Barus, D. P. (2021). Pengaruh Model Pembelajaran Inkuiri Terbimbing dengan Multi Representasi terhadap Keterampilan Proses Sains dan Penguasaan Konsep IPA. Jurnal Basicedu, 5(1), 195-205.

Slameto, S. (2015). Rasional dan elemen perubahan kurikulum 2013. Scholaria: Jurnal Pendidikan Dan Kebudayaan, 5(1), 1-9.

Sugiana, I. N., Harjono, A., Sahidu, H., \& Gunawan, G. (2017). Pengaruh model pembelajaran generatif berbantuan media laboratorium virtual terhadap penguasaan konsep fisika siswa pada materi momentum dan impuls. Jurnal Pendidikan Fisika dan Teknologi, 2(2), 61-65.

Sugiyono, M. (2015). penelitian \& pengembangan (Research and Development/R\&D). Bandung: Penerbit Alfabeta.

Taherdoost, H. (2016). Validity and reliability of the research instrument; how to test the validation of a questionnaire/survey in a research. How to Test the Validation of a Questionnaire/Survey in a Research (August 10, 2016).

Thahir, A., Anwar, C., Saregar, A., Choiriah, L., Susanti, F., \& Pricilia, A. (2020, February). The Effectiveness of STEM Learning: Scientific Attitudes and Students' Conceptual Understanding. In Journal of Physics: Conference Series (Vol. 1467, No. 1, p. 012008). IOP Publishing. 
Thiagarajan, S. (1974). Instructional Development for Teacher of Exceptional Children. Bloomington.

Trianto. (2010). Model Pembelajaran Terpadu. PT Bumi Aksara.

Trilling, Bernie \& Fadel, C. (2009). 21 ST Century Skills:learning For Life In Our Times. Jossey-Bass.

Wahyuni, S., Kosim, K., \& Gunawan, G. (2018). Pengembangan Perangkat Pembelajaran Fisika Berbasis Inkuiri Terbimbing Berbantuan Eksperimen Untuk Meningkatkan Penguasaan Konsep Siswa. Jurnal Pendidikan Fisika dan Teknologi, 4(2), 240246.

Wening, C. J. (2005). Levels of Inquiry : Hierarchies of Pedagogical Practices and Inquiry Processes. Journal Of Physich Teacher Education Online, 2(3), pp.3-11.

Wening, C. J. (2010). Levels of inquiry: Using inquiry spectrum learning sequences to teach science. Journal of Physics Teacher Education Online, 5(3), 11-12.

Zakwandi, R., Yuningsih, E. K., \& Setya, W. (2020). Implementasi Pembelajaran Berbasis Praktikum pada Konsep Taraf Intensitas Bunyi untuk Meningkatkan Penguasaan Konsep Peserta Didik. Jurnal Penelitian Pembelajaran Fisika, 11(1), 75-82. 